\title{
Oxygen Isotopes in Tree Rings from Greenland: A New Proxy of NAO
}

\author{
Chenxi Xu ${ }^{1,2, *}$, Brendan M. Buckley ${ }^{3} \mathbb{D}$, Shih-Yu Simon Wang ${ }^{4} \mathbb{D}$, Wenling An ${ }^{1,2}$, Zhen Li ${ }^{5}$, Takeshi Nakatsuka ${ }^{5}$ \\ and Zhengtang Guo ${ }^{1,2}$
}

1 Key Laboratory of Cenozoic Geology and Environment, Institute of Geology and Geophysics, Chinese Academy of Sciences, Beijing 100029, China; wlan@mail.iggcas.ac.cn (W.A.); ztguo@mail.iggcas.ac.cn (Z.G.)

2 CAS Center for Excellence in Life and Paleoenvironment, Beijing 100044, China

3 Tree Ring Laboratory, Lamont-Doherty Earth Observatory, Columbia University, Palisades, New York, NY 10964, USA; bmb@ldeo.columbia.edu

4 Department of Plants, Soils, and Climate, Utah State University, Logan, UT 84322, USA; simon.wang@usu.edu

5 Graduate School of Environment Studies, Nagoya University, Nagoya 464-8601, Japan;

li.zhen@j.mbox.nagoya-u.ac.jp (Z.L.); nakatsuka.takeshi@f.mbox.nagoya-u.ac.jp (T.N.)

* Correspondence: cxxu@mail.iggcas.ac.cn

check for updates

Citation: Xu, C.; Buckley, B.M.; Wang S.S.; An, W.; Li, Z.; Nakatsuka, T.; Guo, Z. Oxygen Isotopes in Tree Rings from Greenland: A New Proxy of NAO. Atmosphere 2021, 12, 39. https://doi.org/10.3390/ atmos12010039

Received: 17 November 2020 Accepted: 24 December 2020 Published: 30 December 2020

Publisher's Note: MDPI stays neutral with regard to jurisdictional clai$\mathrm{ms}$ in published maps and institutional affiliations.

Copyright: (C) 2020 by the authors. Licensee MDPI, Basel, Switzerland. This article is an open access article distributed under the terms and conditions of the Creative Commons Attribution (CC BY) license (https:// creativecommons.org/licenses/by/ $4.0 /)$.

\begin{abstract}
We present the first Greenlandic tree ring oxygen isotope record $\left(\delta^{18} \mathrm{O}_{\mathrm{GTR}}\right)$, derived from four birch trees collected from the Qinguadalen Valley in southwestern Greenland in 1999 . Our $\delta^{18} \mathrm{O}$ record spans from 1950-1999 and is significantly and positively correlated with winter ice core $\delta^{18} \mathrm{O}$ from southern Greenland. $\delta^{18} \mathrm{O}_{\mathrm{GTR}}$ records are positively correlated with southwestern Greenland January-August mean temperatures. North Atlantic Oscillation (NAO) reconstructions have been developed from a variety of proxies, but never with Greenlandic tree rings, and our $\delta^{18} \mathrm{O}_{\mathrm{GTR}}$ record is significantly correlated with $\mathrm{NAO}(\mathrm{r}=-0.64)$, and spatial correlations with sea-level pressure indicate a classic NAO pressure seesaw pattern. These results may facilitate a longer NAO reconstruction based on long time series of tree ring $\delta^{18} \mathrm{O}$ records from Greenland, provided that subfossil wood can be found in areas vacated by melting glaciers.
\end{abstract}

Keywords: tree ring $\delta^{18} \mathrm{O}$; ice core $\delta^{18} \mathrm{O}$; greenland; North Atlantic Oscillation

\section{Introduction}

Tree rings are one of the most important proxies for paleoclimate studies, due to their high temporal resolution and accurate dating [1,2]. Based on the tree ring oxygen isotope fractionation model [3], the stable oxygen isotope $\left(\delta^{18} \mathrm{O}\right)$ in tree rings is controlled by the $\delta^{18} \mathrm{O} /$ oxygen isotope (signature) of precipitation and relative humidity, both of which are influenced by climate. Therefore, we have used tree ring $\delta^{18} \mathrm{O}$ for climate reconstruction $[4,5]$. Compared to tree ring width (TRW), tree ring $\delta^{18} \mathrm{O}$ sometimes exhibits stronger correlations with climate than ring width [6,7]. Tree ring $\delta^{18} \mathrm{O}$ does not usually exhibit a strong, age-related trend [8-10], and could retain more climatic low frequency variability that might be related to climate [6]. Precipitation $\delta^{18} \mathrm{O}$ is affected by large-scale atmospheric circulation [11], and thus tree ring $\delta^{18} \mathrm{O}$ can reveal a significant link with atmospheric circulation, such as synoptic weather type, ENSO, Arctic Oscillation and Antarctic Oscillation [12-16]. Therefore, tree ring $\delta^{18} \mathrm{O}$ can not only be used for traditional climate variable reconstruction, but may also be exploited for reconstruction of large-scale atmospheric circulation $[13,16]$.

The North Atlantic Oscillation (NAO) is a major feature of the atmospheric circulation over the northern hemisphere with widespread impacts on climate across Europe, Greenland, northern North America, North Africa and Asia, and is characterized as the dipole of sea-level pressure (SLP) between the Azores and Iceland [17-20]. Because of the importance of the NAO, and the limitations that result from temporally limited instrumental data, many NAO index reconstruction studies have been conducted during the last 20 years. 
These studies utilize the earliest instrumental data, historical documentation, ice cores, tree rings and speleothems from across Europe, Northern America and northern Africa to investigate NAO variability and its responses to external forcing [21-27]. However, a detailed review of the published NAO reconstructions showed a lack of agreement between them, particularly on decadal to multi-decadal time scales [27]. Thus, it is necessary to explore a novel, high resolution proxy for the reconstruction of $\mathrm{NAO}$, to improve the quantification of the response of NAO variability to both natural and anthropogenic climate forcings.

Despite the NAO's primary signature around Greenland, Greenlandic tree rings have not been used for NAO reconstructions in previous studies [26,27] (Figure 1a), since limited tree ring research has been conducted in Greenland. Beschel and Webb (1963) demonstrated that Salix glauca and Juniperus communis from western Greenland formed annual rings [28], but did not develop a regional time series for comparison with climate. Kuivenen and Lawson (1982) collected cores of Betula pubescens (birch) from the Qinguadalen Valley of southern Greenland that they successfully cross-dated and correlated with regional temperature [29]. It is these trees that we resampled in 1999 and use in the current study. Precipitation $\delta^{18} \mathrm{O}$ in Greenland is correlated with temperature, which is related to $\mathrm{NAO}$ [30]. We assume that tree ring $\delta^{18} \mathrm{O}$ preserves the precipitation $\delta^{18} \mathrm{O}$ signal and can be used for NAO reconstruction. In the present study, we aim to produce a new tree ring $\delta^{18} \mathrm{O}$ record from Greenland and to examine the possibility of reconstructing NAO using tree ring $\delta^{18} \mathrm{O}$.

\section{Materials and Methods}

In the summer of 1999, co-author Buckley collected birch samples (Betula pubescens) from the Qinguadalen Valley of southwestern Greenland (Figure 1), in order to update the Kuivenen and Lawson (1982) collection. He cross-dated and measured ring width from 28 core samples and developed a tree ring width record that spanned from 1884-1999 (unpublished). In this study, four trees from this collection (Sample ID: QUN24, 25, 30 and 45) were used for oxygen isotope analysis. In order to obtain enough wood material to extract purified cellulose, we selected discernable and relatively wide rings for the establishment of tree ring $\delta^{18} \mathrm{O}$ series. The final timespan of the tree ring oxygen series for each tree is 1950-1999, 1950-1999, 1950-1998 and 1950-1988, respectively. The common period of the individual tree ring oxygen series from the four trees is 1950-1972. The modified plate method [31] was employed to extract $\alpha$-cellulose. We first used a low-speed diamond wheel saw to cut the cores into 1-mm-thick plates, along surfaces perpendicular to the cellulose fiber directions. Then we packed the plate by two Teflon punch sheets and put it into a glass tube for chemical reactions. Next, we followed the Jayme and Wise method to conduct the chemical protocol in order to extract $\alpha$-cellulose from the tree rings $[32,33]$. The glass tube with the plate was treated with an acidified $\mathrm{NaClO}_{2}$ solution in a water bath $\left(70{ }^{\circ} \mathrm{C}\right.$ ) for $60 \mathrm{~min}$ to remove lignin, and this step had to be repeated several times until the color of the plate turned white. To remove hemicellulose, a $17 \mathrm{wt} \% \mathrm{NaOH}$ solution was poured into the glass tube in a water bath $\left(80^{\circ} \mathrm{C}\right)$ for $60 \mathrm{~min}$, and this was repeated three times. After that, the wood plate was gently washed with a diluted $\mathrm{HCl}$ solution and distilled water. The wood plate was then treated with toluene and ethanol (1:1) at room temperature for $10 \mathrm{~min}$, then with acetone overnight to remove lipids. Finally, the cellulose plate was dried in an oven for three hours and the rings were cut from each cellulose plate with a scalpel under a binocular microscope at annual resolution.

The $\alpha$-cellulose samples $(80-260 \mu \mathrm{g})$ were wrapped into silver foil, and tree ring cellulose oxygen isotope values were measured using an isotope ratio mass spectrometer (Delta V Advantage, Thermo Electron Corporation, Bremen, Germany) interfaced with an elemental analyzer (TC/EA) at the Research Institute for Humanity and Nature, Japan. There are several gaps for the tree ring $\delta^{18} \mathrm{O}$ data due to narrow rings from which we could not collect enough cellulose for measurement (Figure 2). Cellulose $\delta^{18} \mathrm{O}$ values were calculated by comparison with analysis of Merck cellulose (laboratory working standard) which has been calibrated with IAEA-C3. Merck cellulose was inserted after every eight 
tree samples during the measurements. Oxygen isotope results are presented in $\delta$ notation as the per mil (\%o) deviation from Vienna Standard Mean Ocean Water (VSMOW), $\delta^{18} \mathrm{O}$ $=[($ Rsample $/$ Rstandard $)-1] \times 1000$, where Rsample and Rstandard are the ${ }^{18} \mathrm{O} /{ }^{16} \mathrm{O}$ ratios of the sample and standard, respectively. The analytical uncertainties on repeated measurements of the Merck cellulose were approximately $\pm 0.2 \%$ o $(n=32)$.

The relationship among $\delta^{18} \mathrm{O}$ from different trees was quantified using Pearson's correlation coefficient (r). The expressed population signal (EPS) is used to measure the internal coherence of a tree ring chronology. Generally, it is widely considered that EPS values exceeding 0.85 indicate that the composite record represents the mean variance of the population and yields a signal relatively free of noise because of individual variations [34]. We also calculated the average correlation (Rbar) to analyze the synchrony of variations of tree ring $\delta^{18} \mathrm{O}$. It is the average correlation of individual correlation coefficients among inter-tree $\delta^{18} \mathrm{O}$. In addition, to evaluate the relationships between climate variables and tree ring $\delta^{18} \mathrm{O}$, we calculated Pearson's correlation coefficients $\mathrm{r}$ between tree ring $\delta^{18} \mathrm{O}$ values and monthly resolved instrumental temperature. Student's t-test was used to evaluate the significance of the correlation coefficients. To test the spatial coherence between the tree ring $\delta^{18} \mathrm{O}$ and local to regional climatic variations, we computed spatial Pearson's correlation coefficient between tree ring $\delta^{18} \mathrm{O}$ and the CRU TS 4.02 gridded temperature, and sea-level pressure (SLP) from the NCEP Reanalysis data (https:/ / www.esrl.noaa.gov/psd/) and the Standardized Precipitation Evapotranspiration Index (SPEI) [35] using the KNMI climate explorer software (Royal Netherlands Meteorological Institute; http: / / climexp.knmi.nl). Furthermore, a monthly NAO index from the Climate Prediction center of NOAA [36] was employed to evaluate the relationship between tree ring $\delta^{18} \mathrm{O}$ and NAO.
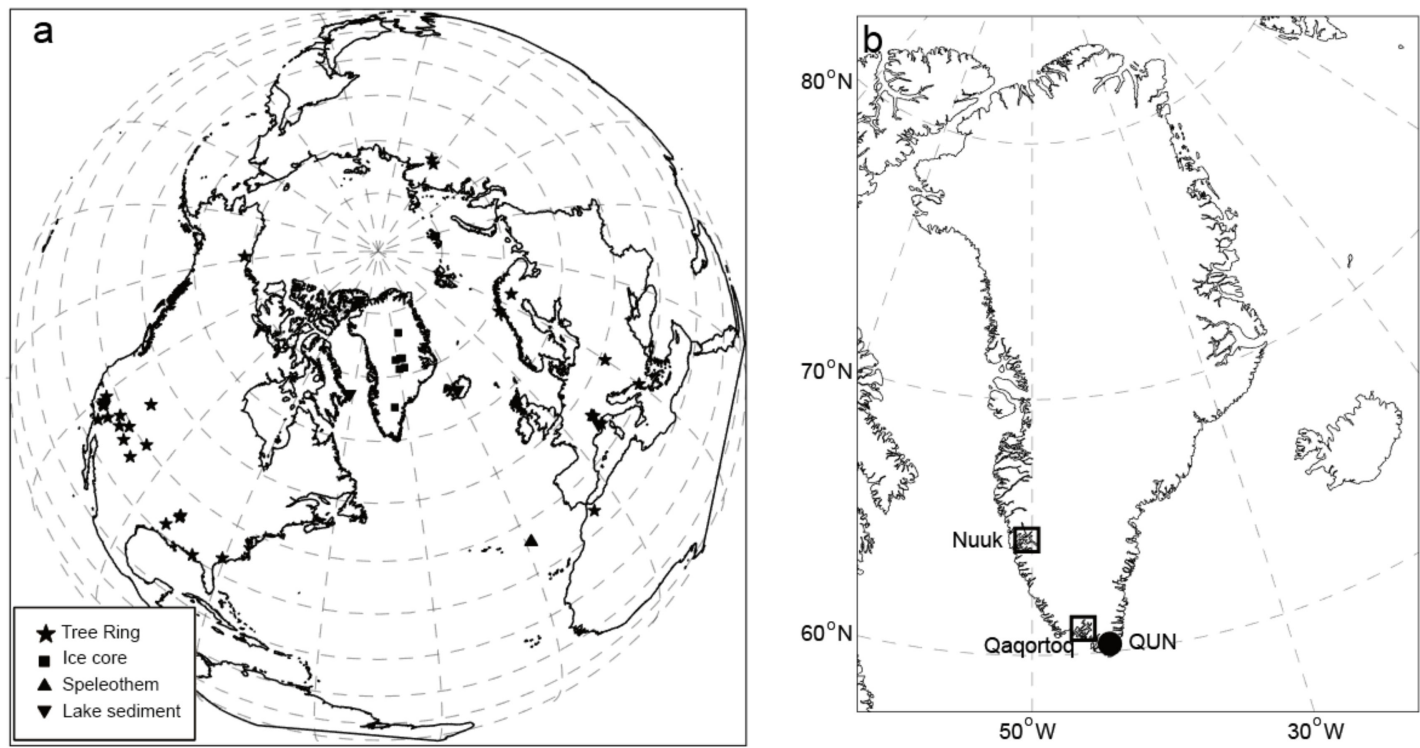

Figure 1. (a) Location of the ice cores, lake sediments, speleothems and tree rings that were used for NAO (North Atlantic Oscillation) reconstructions (modified from [26]). (b) Location of sampling site for the presented tree ring oxygen isotope (spot) and Nuuk and Qaqortoq meteorological stations (square).

\section{Results and Discussion}

\subsection{Inter-Tree $\delta^{18} \mathrm{O}$ Variability and Regional $\delta^{18} \mathrm{O}$ Chronology}

The Greenland Tree Ring oxygen isotope time series $\left(\delta^{18} \mathrm{O}_{\mathrm{GTR}}\right)$ derived from four birch trees is shown in Figure 2, while the underlying data can be found in the Supplementary Materials. $\delta^{18} \mathrm{O}$ values in all trees fall within the same range, with values from $22.7-$ $28.4 \%$ and an average of $25.3 \%$ o $\left( \pm 1.08 \%\right.$ ). The $\delta^{18} \mathrm{O}$ mean of QUN 24, 25, 30 and 45 during the common period of $1950-1972$ is $25.61 \%$ o $( \pm 1.12 \%$ o $), 25.83 \%$ o $( \pm 1.11 \%$ o $), 25.22 \%$ $( \pm 0.99 \%$ o and $25.50 \%$ o $( \pm 1.07 \%$ ) , respectively. We also calculated the standard deviation of $\delta^{18} \mathrm{O}$ in the four trees for each year, which exhibited a range of $0.1-1.3 \%$, smaller than 
previous studies $\left(1 \% \circ-4 \%\right.$ ) [37]. Inter-tree $\delta^{18} \mathrm{O}$ correlations are very high (EPS > 0.85) and the average correlation among inter-tree $\delta^{18} \mathrm{O}$ (Rbar) is 0.9 (Table 1, Figure 2). By way of comparison, Dinis et al. (2019) reported Rbar of 0.59 for $\delta^{18} \mathrm{O}$ from Labrador black spruce [15], while Naulier et al. (2014) reported an Rbar of 0.5 for black spruce $\delta^{18} \mathrm{O}$ from northeastern Québec [38].

Table 1. Correlation coefficients among tree ring oxygen isotopes.

\begin{tabular}{cccc}
\hline Correlation & QUN24 & QUN25 & QUN30 \\
\hline QUN25 & $0.94^{*}$ & & \\
QUN30 & $0.85^{*}$ & $0.91 *$ & $0.86 *$ \\
QUN45 & $0.94^{*}$ & $0.91 *$ & $0.86^{*}$ \\
\hline
\end{tabular}

* indicates $p<0.01$.

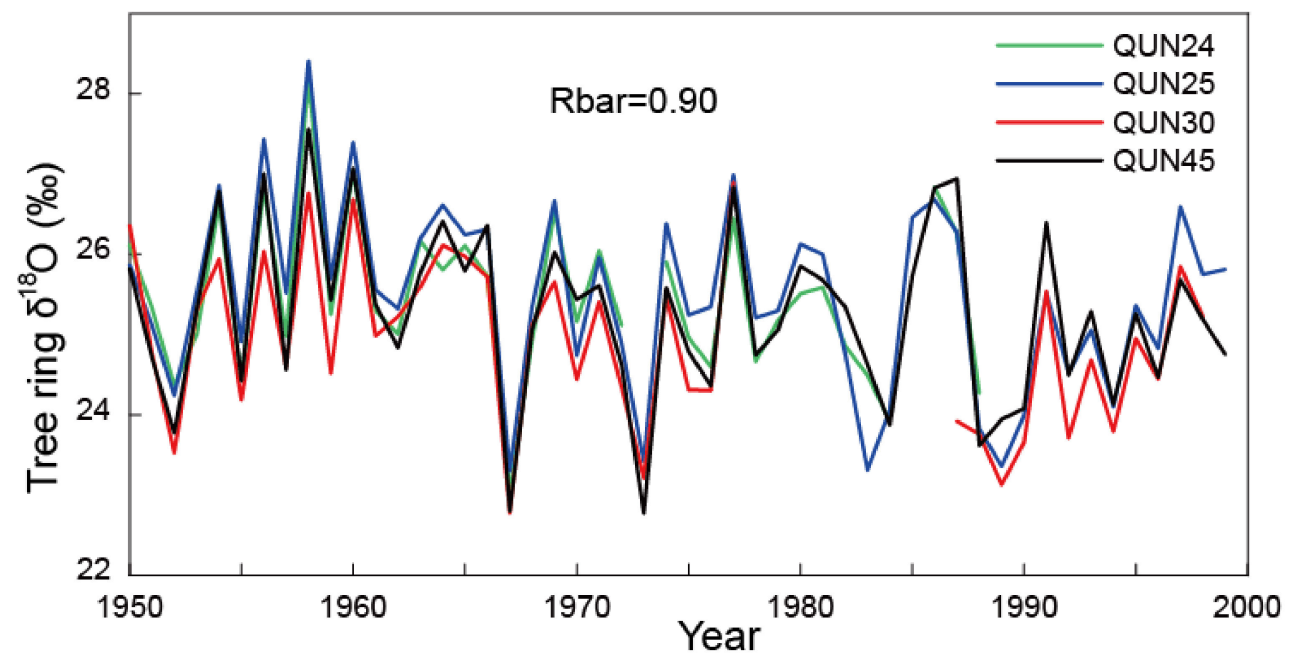

Figure 2. Tree ring oxygen isotope time series from four birch during the period of 1950-1999.

Because $\delta^{18} \mathrm{O}$ shows consistent between-tree variations, we developed a regional $\delta^{18} \mathrm{O}$ chronology $\left(\delta^{18} \mathrm{O}_{\mathrm{GTR}}\right)$ by averaging the four $\delta^{18} \mathrm{O}$ time series (QUN 24, 25, 30 and 45). The first-order autocorrelation for $\delta^{18} \mathrm{O}_{\mathrm{GTR}}$ is low $(0.01)$, which indicates the tree ring $\delta^{18} \mathrm{O}$ of the current year is little affected by the tree ring $\delta^{18} \mathrm{O}$ in previous year(s).

\subsection{Comparison between Tree Ring $\delta^{18} \mathrm{O}$ and Ice Core $\delta^{18} \mathrm{O}$}

Tree ring $\delta^{18} \mathrm{O}$ is controlled by precipitation $\delta^{18} \mathrm{O}$ and relative humidity [3], while ice core $\delta^{18} \mathrm{O}$ is derived from precipitation $\delta^{18} \mathrm{O}$ [39]. Figure 3 shows a comparison of $\delta^{18} \mathrm{O}_{\mathrm{GTR}}$ with winter/summer ice core $\delta^{18} \mathrm{O}$ in Greenland [40] during the common period (for DYE-3 = 1950-1978; for Crete = 1950-1973; and for GRIP = 1950-1979). The spatial correlation between $\delta^{18} \mathrm{O}_{\mathrm{GTR}}$ and ice core $\delta^{18} \mathrm{O}$ is inversely correlated with distance, for summer and winter (Supplementary Materials Figure S1), suggesting a strong locality in Greenland's climate that shows different regimes between the southwestern coastline and inner, high-elevation regions. 

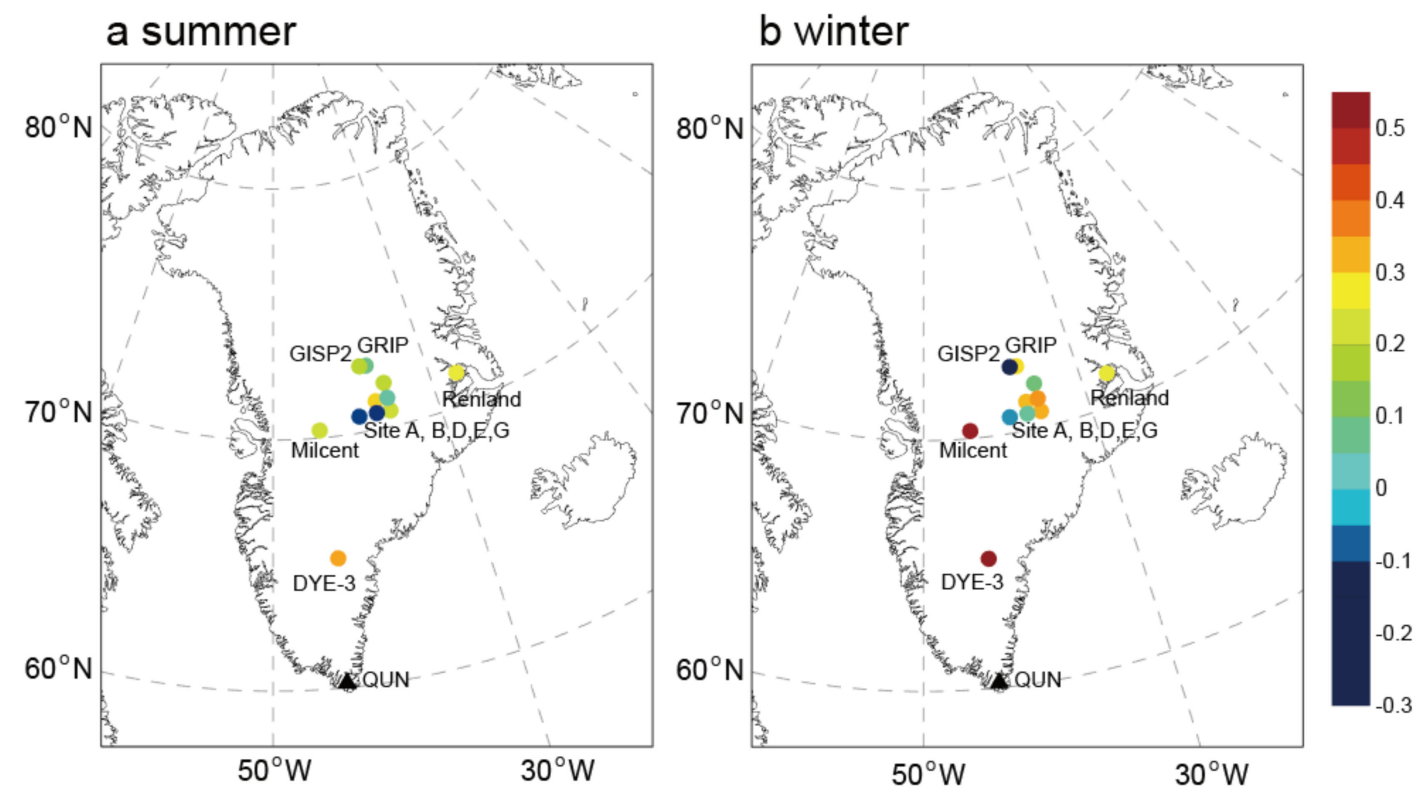

Figure 3. Spatial correlations between tree ring $\delta^{18} \mathrm{O}$ with summer $(\mathbf{a})$ and winter $(\mathbf{b})$ ice core $\delta^{18} \mathrm{O}$. The time spans of the ice core records are presented in Table S1.

It should be noted that $\delta^{18} \mathrm{O}_{\mathrm{GTR}}$ showed higher correlations with ice core $\delta 18 \mathrm{O}$ in winter rather than summer, even though trees mostly grow in summer. For example, the correlation between tree ring and summer/winter DYE- $3 \delta^{18} \mathrm{O}$ is 0.27 and 0.45 , respectively. There are two possible reasons: first, the trees in Greenland could have absorbed more winter precipitation or snow/ice than summer precipitation. Some studies have suggested that winter snowmelt comprises a large portion of the source water for trees [41], such that previous winter snow/ice that melts at the beginning of the growth season is taken up by the trees in summer. This could explain the significant correlation between tree ring $\delta^{18} \mathrm{O}$ and winter ice core $\delta^{18} \mathrm{O}$. Second, summer precipitation $\delta^{18} \mathrm{O}$ used by trees in the growing season is modified by transpiration [3], which weakens both the signature of summer precipitation $\delta^{18} \mathrm{O}$ imprinted in trees, and the correlations between tree ring and summer ice core $\delta^{18} \mathrm{O}$.

Previous studies reported that tree ring $\delta^{18} \mathrm{O}$ reflects prior winter precipitation and temperature, rather than summer $[4,42]$. For example, tree ring $\delta^{18} \mathrm{O}$ from the southeastern Tibetan Plateau showed variations similar to those in annual ice core $\delta^{18} \mathrm{O}$ in the southeastern Tibetan Plateau (Dr. Weiling An, personal communications). The significant correlation between tree ring $\delta^{18} \mathrm{O}$ and ice core $\delta^{18} \mathrm{O}$ provides the opportunity to obtain a robust climate reconstruction. Because cross-dating for the trees at our site is robust and has an annual resolution, comparing ice core and tree ring $\delta^{18} \mathrm{O}$ should be helpful for accurate cross-dating. Furthermore, high-resolution seasonal tree ring $\delta^{18} \mathrm{O}$ with distinctive winter and summer signals may improve ice core dating and provide more detailed climate information. For now, however, our tree ring records extend only into the late 19th century, so older living trees and subfossil trees emerging from sediment and melting ice could be targeted for in future.

\subsection{Climatic Implications of Tree Ring $\delta^{18} \mathrm{O}$}

Previous studies in northeast Canada have shown that tree ring $\delta^{18} \mathrm{O}$ has positive correlations with summer temperature and negative correlations with summer rainfall $[15,38,43]$. Therefore, we conducted correlation analyses between $\delta^{18} \mathrm{O}_{\mathrm{GTR}}$ and temperature at Nuuk and Qaqortoq for the period 1950-1999 (Figure 4). We show a positive correlation with current January-August temperature $(\mathrm{r}=0.57$ for Nuuk and $\mathrm{r}=0.58$ for Qaqortaq; $\mathrm{n}=55 ; p<0.001)$, which indicates that the main climate signal influencing tree ring $\delta^{18} \mathrm{O}$ originates from the January-August temperature. Spatial correlations between tree ring $\delta^{18} \mathrm{O}$ and temperature 
also support their relationship (Figure 5a). The significant correlation between $\delta^{18} \mathrm{O}_{\mathrm{GTR}}$ and temperature can be explained by the positive relationship between precipitation $\delta^{18} \mathrm{O}$ and temperature, which is used widely for ice-core-based temperature reconstruction [21,44]. Before being absorbed by trees growing in summer, isotopic fractionation processes associated with precipitation formation before and during the growing season depend directly on temperature variations. The higher temperatures will result in more $\delta^{18} \mathrm{O}$ enrichment in the precipitation and soil water, and thus in trees.

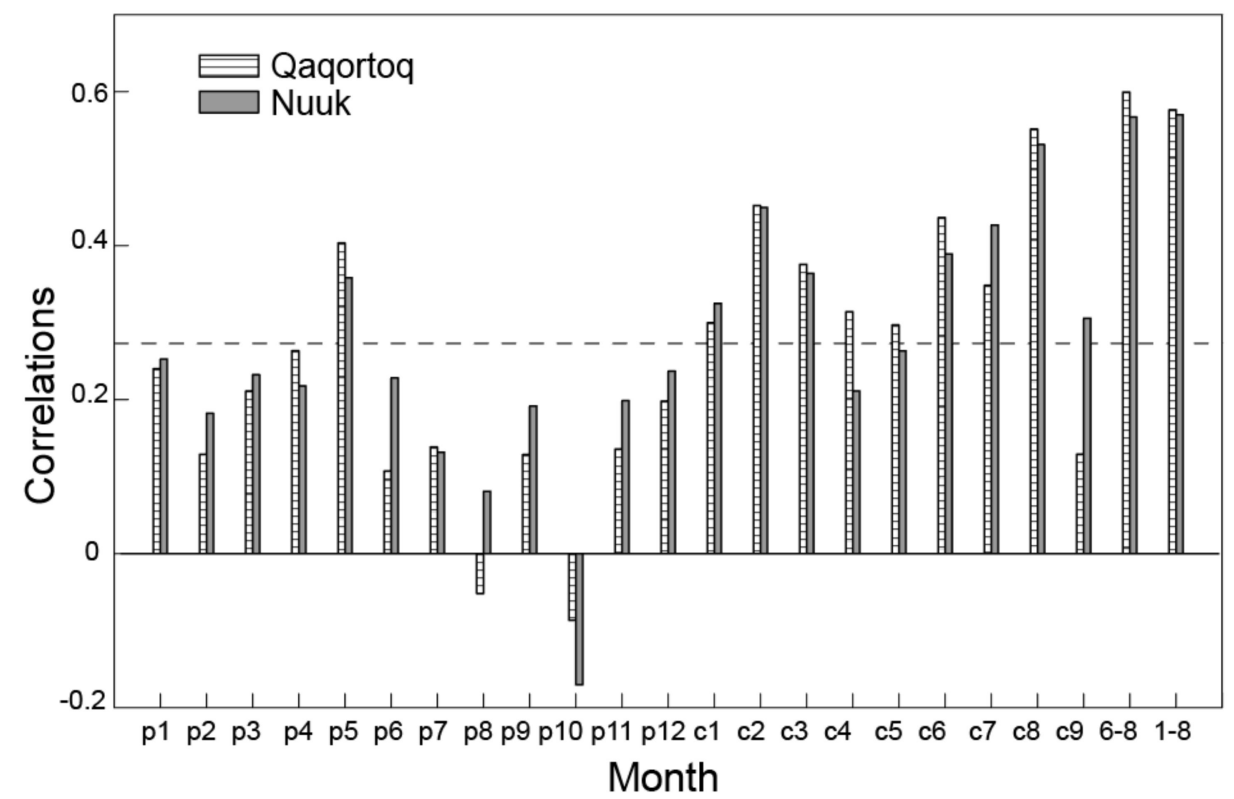

Figure 4. Correlations between tree ring $\delta^{18} \mathrm{O}$ with monthly temperature at Nuuk and Qaqortoq station during the period of 1950-1999. Numbers in $x$-axis represent the months of the year, and numbers with a " $\mathrm{p}$ " and " $\mathrm{c}$ " prefix indicate the previous year and current year, respectively. The dashed line indicates the $95 \%$ confidence level threshold.

Relative humidity is another controlling factor for tree ring $\delta^{18} \mathrm{O}$ during the growth season [3]. Local relative humidity data are not available, so we used the summertime Standardized Precipitation Evapotranspiration Index (SPEI) to evaluate evapotranspiration influences on tree ring $\delta^{18} \mathrm{O}$. We found a negative correlation between SPEI and $\delta^{18} \mathrm{O}_{\mathrm{GTR}}$ (Figure $5 b$ ), indicating that a higher SPEI is associated with relatively wet conditions and reduced evapotranspiration. Such conditions would result in depletion of leaf water and soil water $\delta^{18} \mathrm{O}$, and subsequently lower cellulose $\delta^{18} \mathrm{O}$. Positive correlations between tree ring $\delta^{18} \mathrm{O}$ with temperature and negative correlations with moisture were also reported in northeast Canada $[38,43]$. The correlations between tree ring $\delta^{18} \mathrm{O}$ and temperature are higher than with SPEI (Figure 5), which reveal that precipitation $\delta^{18} \mathrm{O}$ rather than relative humidity has the dominant influence over tree ring $\delta^{18} \mathrm{O}$ at our study site in southwestern Greenland. 
a. Temperature

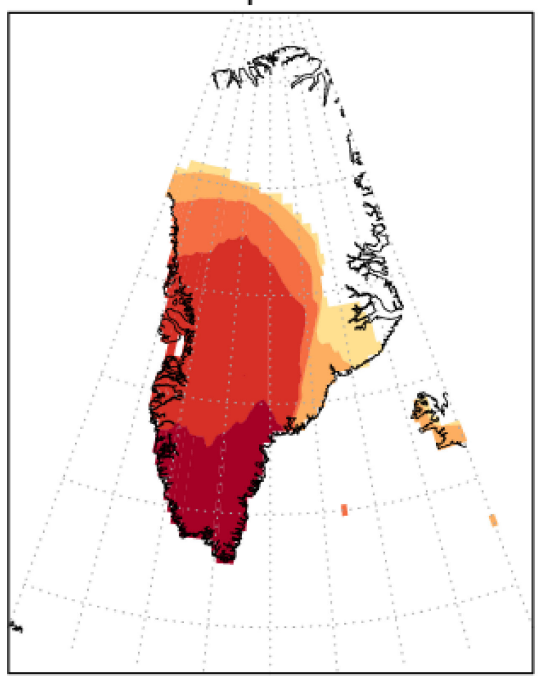

b. SPEI

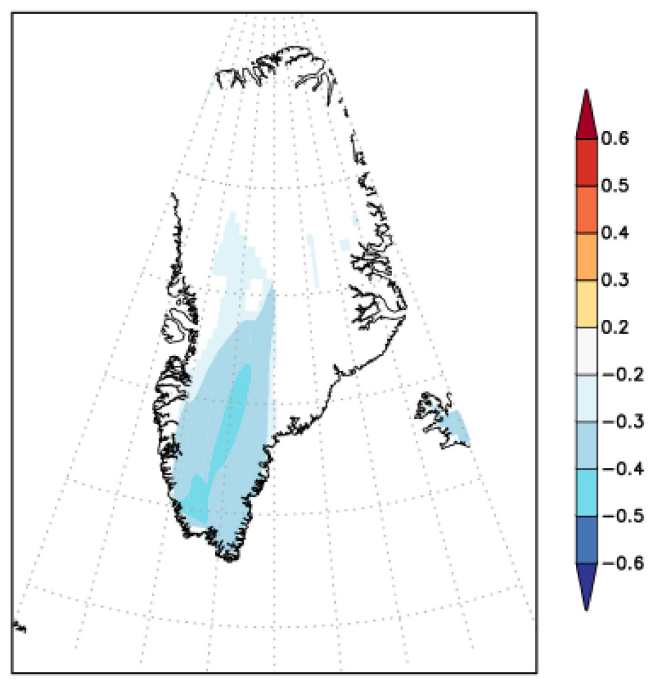

Figure 5. Spatial correlations between tree ring $\delta^{18} \mathrm{O}$ with January-August air temperature (a) and June-August SPEI (b) for the period of 1950-1999. Correlations not significant at the $95 \%$ level have been masked out.

\subsection{Relationship with $N A O$}

As shown in Figure 6, we find significant negative correlations between tree ring $\delta^{18} \mathrm{O}$ and $\mathrm{AO} / \mathrm{NAO}$, which are strongest for the January-August NAO index $(\mathrm{r}=-0.64, p<0.001$, $\mathrm{n}=50)$. A similarly strong correlation $(\mathrm{r}=-0.64, p<0.001, \mathrm{n}=50)$ is also found with the Arctic Oscillation index (AO). Interestingly, the relationship between NAO and Greenland ice core $\delta^{18} \mathrm{O}$ is relatively weak (Figure S2). To evaluate the relationship between NAO and tree ring $\delta^{18} \mathrm{O}$ further, we plot our results from spatial correlation analyses between $\delta^{18} \mathrm{O}_{\mathrm{GTR}}$ and sea-level pressure (SLP) during the different months in Figure 7. We show that $\delta 18 \mathrm{O}_{\text {GTR }}$ is positively correlated with SLP in the high-latitude area centered in Greenland and negatively correlated with SLP in the mid-latitude Atlantic, both in winter (Figure 7a) and summer (Figure $7 b$ ). This pattern reflects the classic NAO pattern [18]. By conducting the same correlation analysis with SST, $\delta^{18} \mathrm{O}_{\mathrm{GTR}}$ showed strong correlations with SST anomalies around the southern coastlines of Greenland (Figure 7d-f). This localized SST response with tree ring $\delta^{18} \mathrm{O}$, with the absence of any broader or tropical signal, suggests that tree ring $\delta^{18} \mathrm{O}$ mainly reflects atmospheric variability which is related to NAO. Tree ring $\delta^{18} \mathrm{O}$ is mainly controlled by precipitation $\delta^{18} \mathrm{O}$, which is in turn controlled by temperature of the air mass during precipitation and the isotopic fractionation processes that follow (for either rain or snow). Therefore, a positive phase of NAO brings lower temperatures to Greenland and depleted precipitation $\delta^{18} \mathrm{O}$, which is in turn reflected in lower tree ring $\delta^{18} \mathrm{O}$.

We next compared $\delta^{18} \mathrm{O}_{\mathrm{GTR}}$ with previous NAO reconstructions during the common period of 1950-1999, revealing negative correlations with a couple of NAO reconstructions: one based on historical documents across Europe [23] $(\mathrm{r}=-0.47, p<0.01)$ and the other based on tree rings from eastern North America, Morocco, Europe and ice cores in Greenland [24] $(\mathrm{r}=-0.51, p<0.01)$. These significant correlations between independent proxies indicate that $\delta^{18} \mathrm{O}_{\mathrm{GTR}}$ is as effective a proxy of $\mathrm{NAO}$ as other proxy variables and can explain around $41 \%$ of the actual variance of NAO, which is comparable to Cook et al. (2002) [24]. It is noted that our $\delta^{18} \mathrm{O}_{\mathrm{GTR}}$ record is derived from only four trees, while the Cook et al. (2002) NAO reconstruction is based on 367 records [24]. Therefore, we believe we have demonstrated the strong climate signal preserved in tree ring $\delta^{18} \mathrm{O}$ from Greenland, which could provide an opportunity for climate reconstruction with limited samples. However, a much larger data set with a longer time span is highly desirable. Future efforts are needed to look for older and subfossil trees, in order to use tree ring $\delta^{18} \mathrm{O}$ data from Greenland as a proxy of NAO. As a matter of fact, many long tree ring $\delta^{18} \mathrm{O}$ chronologies have been successfully established by combining living trees with subfossil 
trees preserved in lake sediments $[43,45]$ and then cross-dating these stems to determine the ages of subfossil trees [46]. There are many lakes in Greenland [47,48], so a long-term tree ring $\delta^{18} \mathrm{O}$ record from living trees and subfossil trees could be established in future.

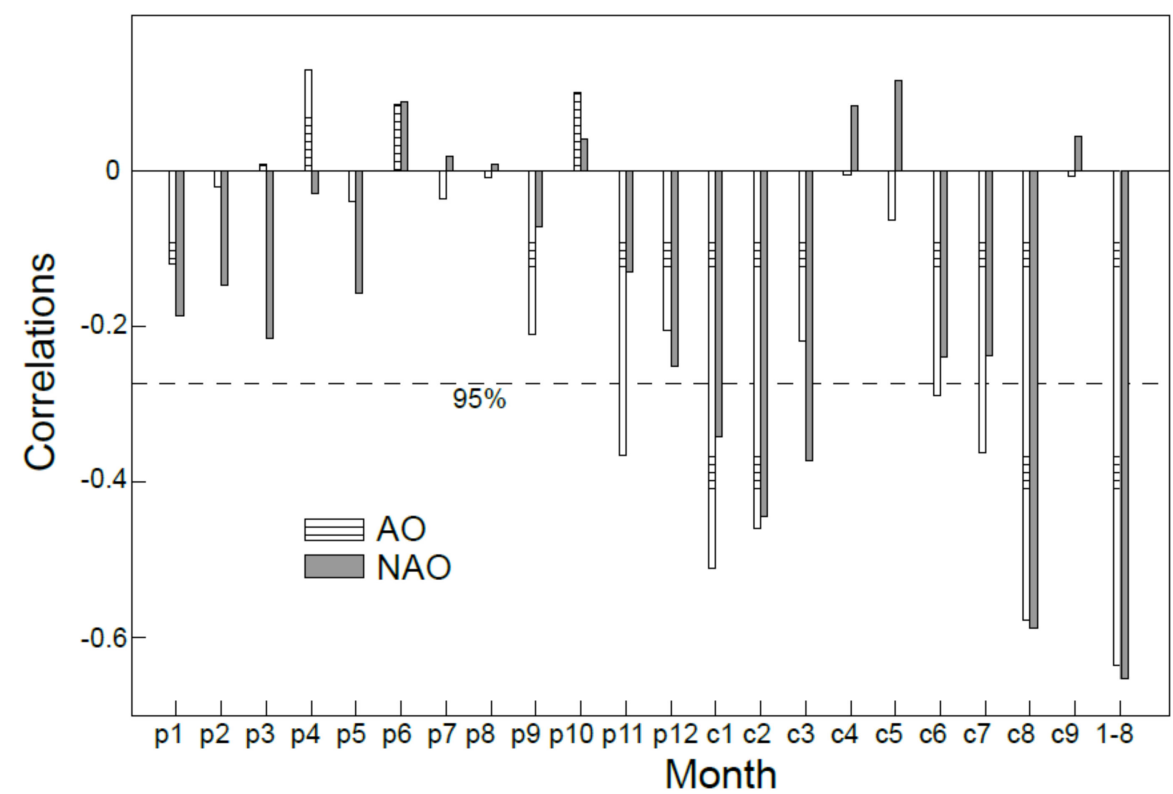

Figure 6. Correlations between tree ring oxygen isotope with NAO/AO during the period of 19501999. Numbers in the $x$-axis represent the months of the year, and numbers with a " $\mathrm{p}$ " and " $\mathrm{c}$ " prefix indicate the previous year and current year, respectively.

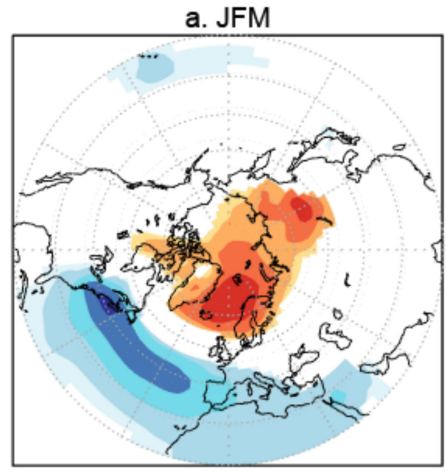

d. JFM

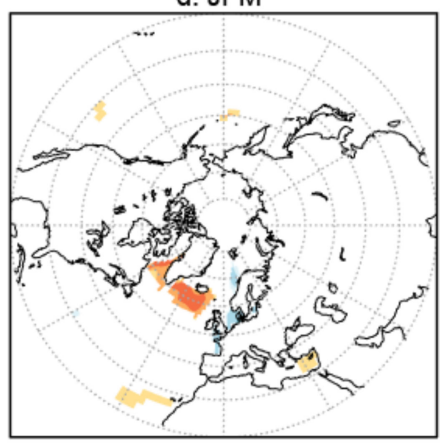

b. JJA

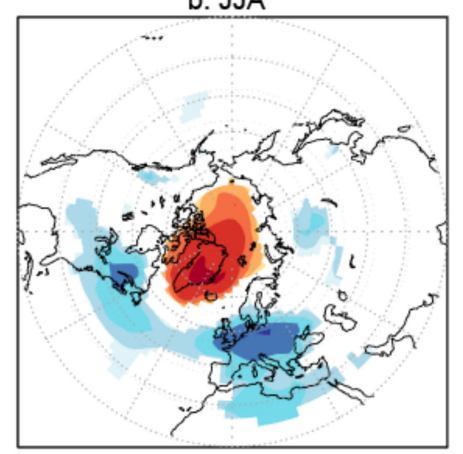

e. JJA

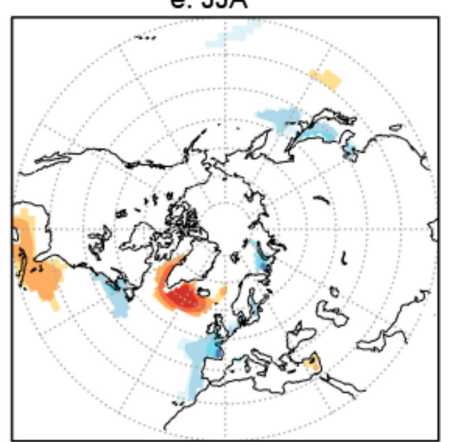

c. J-A

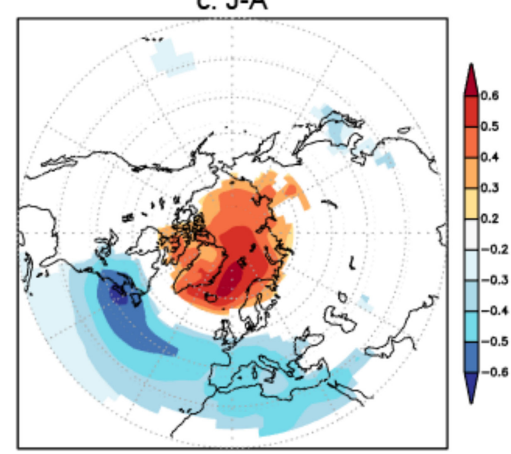

f. J-A

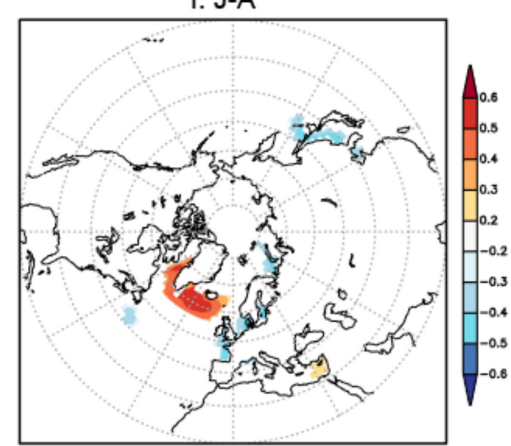

Figure 7. Spatial correlations between tree ring oxygen isotope with sea-level pressure (a-c) and sea surface temperature (d-f) during the period of 1950-1999. Correlations not significant at the 95\% level have been masked out. 


\section{Conclusions}

We present here the first tree ring $\delta^{18} \mathrm{O}$ chronology from Greenland, based on four birches that span the period of $1950-1999$. These four tree ring $\delta^{18} \mathrm{O}$ time series are highly coherent and the resultant record $\left(\delta^{18} \mathrm{O}_{\mathrm{GTR}}\right)$ is significantly correlated with winter ice core $\delta^{18} \mathrm{O}$ in southern Greenland. We demonstrate that tree ring $\delta^{18} \mathrm{O}$ has a significant correlation with temperature and NAO during the early half of the year, and is therefore a promising proxy for reconstructing NAO over Greenland.

Supplementary Materials: The following are available online at https:/ /www.mdpi.com/2073-4 433/12/1/39/s1, Figure S1: The variations of correlations between tree ring oxygen isotopes with summer (a) and winter (b) ice core oxygen isotope with that of distances between tree ring sampling site and ice core sites presented in Figure 3, Figure S2: Correlations between tree ring oxygen isotope with NAO/AO during the period of 1950-1970. Numbers in $x$-axis represent the months of the year, and numbers with a " $\mathrm{p}$ " and " $\mathrm{c}$ " prefix indicate the previous year and current year, respectively. Table S1: The time span of ice cores presented in Figure 3.

Author Contributions: Conceptualization, C.X. and B.M.B.; methodology, C.X.; W.A.; Z.L.; T.N.; formal analysis, C.X.; S.-Y.S.W.; B.M.B.; Z.G.; writing—original draft preparation, C.X; writingreview and editing, C.X.; S.-Y.S.W.; B.M.B.; W.A.; Z.L.; T.N.; Z.G. All authors have read and agreed to the published version of the manuscript.

Funding: This study was funded by the National Natural Science Foundation of China, Grant Number: 41,888,101,42,022,059,41,630,529, 41,672,179, 41,690,114; the Chinese Academy of Sciences (CAS) Pioneer Hundred Talents Program, the National Key R\&D Program of China, Grant Number: 2017YFE0112800; the Strategic Priority Research Program of the Chinese Academy of Sciences, Grant Number: XDB26020000 and XDA13010106. The collection of the QUN core samples was funded by the Lamont Climate Center. Lamont Contribution Number 8464. Simon Wang is supported by NSF P2C2 award number-1903721.

Institutional Review Board Statement: Not applicable.

Informed Consent Statement: Not applicable.

Data Availability Statement: The data presented in this study can be accessed from WDC for Geophysics, Beijing (http://wdc.geophys.ac.cn, DOI:10.12197/2020GA022).

Conflicts of Interest: The authors declare no conflict of interest.

\section{References}

1. Fritts, H.C. Tree Rings and Climate; Academic: London, UK, 1976.

2. Cook, E.R.; Anchukaitis, K.J.; Buckley, B.M.; D'Arrigo, R.D.; Jacoby, G.C.; Wright, W.E. Asian Monsoon Failure and Megadrought During the Last Millennium. Science 2010, 328, 486-489. [CrossRef] [PubMed]

3. Roden, J.S.; Lin, G.; Ehleringer, J.R. A mechanistic model for interpretation of hydrogen and oxygen isotope ratios in tree-ring cellulose. Geochim. Cosmochim. Acta 2000, 64, 21-35. [CrossRef]

4. Treydte, K.; Schleser, G.H.; Helle, G.; Frank, D.C.; Winiger, M.; Haug, G.H.; Esper, J. The twentieth century was the wettest period in northern Pakistan over the past millennium. Nat. Cell Biol. 2006, 440, 1179-1182. [CrossRef] [PubMed]

5. Xu, C.; An, W.; Wang, S.-Y.S.; Yi, L.; Ge, J.; Nakatsuka, T.; Sano, M.; Guo, Z. Increased drought events in southwest China revealed by tree ring oxygen isotopes and potential role of Indian Ocean Dipole. Sci. Total Environ. 2019, 661, 645-653. [CrossRef] [PubMed]

6. Gagen, M.; McCarroll, D.; Loader, N.J.; Robertson, I. Stable Isotopes in Dendroclimatology: Moving Beyond 'Potential'. Dendroclimatology 2011, 11, 147-172.

7. Xu, C.; Sano, M.; Nakatsuka, T. Tree ring cellulose $\delta 180$ of Fokienia hodginsii in northern Laos: A promising proxy to re-construct ENSO? J. Geophys. Res. 2011, 116, D24109.

8. Young, G.H.F.; Demmler, J.C.; Gunnarson, B.E.; Kirchhefer, A.J.; Loader, N.J.; McCarroll, D. Age trends in tree ring growth and isotopic archives: A case study of Pinus sylvestris L. from northwestern Norway. Global Biogeochem. Cycles 2011, 25, GB2020. [CrossRef]

9. Sano, M.; Tshering, P.; Komori, J.; Fujita, K.; Xu, C.; Nakatsuka, T. May-September precipitation in the Bhutan Himalaya since 1743 as reconstructed from tree ring cellulose 8180 . J. Geophys. Res. Atmos. 2013, 118, 8399-8410. [CrossRef]

10. Xu, C.; Ge, J.; Nakatsuka, T.; Yi, L.; Zheng, H.; Sano, M. Potential utility of tree ring $\delta 18$ O series for reconstructing precipitation records from the lower reaches of the Yangtze River, southeast China. J. Geophys. Res. Atmos. 2016, 121, 3954-3968. [CrossRef] 
11. Ichiyanagi, K.; Yamanaka, M.D. Interannual variation of stable isotopes in precipitation at Bangkok in response to El NiñoSouthern Oscillation. Hydrol. Process. 2005, 19, 3413-3423. [CrossRef]

12. Saurer, M.; Kress, A.; Leuenberger, M.; Rinne, K.T.; Treydte, K.S.; Siegwolf, R.T.W. Influence of atmospheric circulation patterns on the oxygen isotope ratio of tree rings in the Alpine region. J. Geophys. Res. Space Phys. 2012, 117, 05118. [CrossRef]

13. Xu, C.; Sano, M.; Nakatsuka, T. A 400-year record of hydroclimate variability and local ENSO history in northern Southeast Asia inferred from tree-ring 818 O. Palaeogeogr. Palaeoclim. Palaeoecol. 2013, 386, 588-598. [CrossRef]

14. Xu, C.; Sano, M.; Dimri, A.P.; Ramesh, R.; Nakatsuka, T.; Shi, F.; Guo, Z. Decreasing Indian summer monsoon on the northern Indian sub-continent during the last 180 years: Evidence from five tree-ring cellulose oxygen isotope chronologies. Clim. Past 2018, 14, 653-654. [CrossRef]

15. Dinis, L.; Bégin, C.; Savard, M.M.; Marion, J.; Brigode, P.; Alvarez, C. Tree-ring stable isotopes for regional discharge reconstruction in eastern Labrador and teleconnection with the Arctic Oscillation. Clim. Dynam. 2019, 53, 3625-3640. [CrossRef]

16. Meier, W.J.-H.; Aravena, J.-C.; Jaña, R.; Braun, M.H.; Hochreuther, P.; Soto-Rogel, P.; Grießinger, J. A tree-ring $\delta 18 \mathrm{O}$ series from southernmost Fuego-Patagonia is recording flavors of the Antarctic Oscillation. Glob. Planet. Chang. 2020, 195, 103302. [CrossRef]

17. Hurrell, J.W. Decadal Trends in the North Atlantic Oscillation: Regional Temperatures and Precipitation. Science 1995, 269, 676-679. [CrossRef]

18. Hurrell, J.W.; Kushnir, Y.; Ottersen, G.; Visbeck, M. An overview of the North Atlantic Oscillation. Geophys. Monogr. Am. Geophys. Union 2003, 134, 1-36.

19. Casado, M.; Ortega, P.; Masson-Delmotte, V.; Risi, C.; Swingedouw, D.; Daux, V.; Genty, D.; Maignan, F.; Solomina, O.; Vinther, B.M.; et al. Impact of precipitation intermittency on NAO-temperature signals in proxy records. Clim. Past 2013, 9, 871-886. [CrossRef]

20. Goswami, B.N.; Madhusoodanan, M.S.; Neema, C.P.; Sengupta, D. A physical mechanism for North Atlantic SST influence on the Indian summer monsoon. Geophys. Res. Lett. 2006, 33, 024803. [CrossRef]

21. Jones, P.D.; Jonsson, T.; Wheeler, D. Extension to the North Atlantic oscillation using early instrumental pressure observations from Gibraltar and south-west Iceland. Int. J. Climatol. 1997, 17, 1433-1450. [CrossRef]

22. Appenzeller, C.; Stocker, T.F.; Anklin, M. North Atlantic Oscillation Dynamics Recorded in Greenland Ice Cores. Science 1998, 282, 446-449. [CrossRef] [PubMed]

23. Luterbacher, J.; Xoplaki, E.; Dietrich, D.; Jones, P.D.; Davies, T.D.; Portis, D.; Gonzalez-Rouco, J.F.; Storch, H.V.; Gyalistras, D.; Casty, C. Extending North Atlantic Oscillation reconstructions back to 1500. Atmos. Sci. Lett. 2001, 2, 114-124. [CrossRef]

24. Cook, E.R.; D’Arrigo, R.; Mann, M.E. A well-verified, multiproxy reconstruction of the winter North Atlantic Oscillation index since A.D. 1400. J. Clim. 2002, 15, 1754-1764.

25. Trouet, V.; Esper, J.; Graham, N.E.; Baker, A.; Scourse, J.D.; Frank, D.C. Persistent Positive North Atlantic Oscillation Mode Dominated the Medieval Climate Anomaly. Science 2009, 324, 78-80. [CrossRef]

26. Ortega, P.; Lehner, F.; Swingedouw, D.; Masson-Delmotte, V.; Raible, C.C.; Casado, M.; Yiou, P. A model-tested North Atlantic Oscillation reconstruction for the past millennium. Nat. Cell Biol. 2015, 523, 71-74. [CrossRef]

27. Cook, E.R.; Kushnir, Y.; Smerdon, J.E.; Williams, A.P.; Anchukaitis, K.J.; Wahl, E.R. A Euro-Mediterranean tree-ring recon-struction of the winter NAO index since 910 CE. Clim. Dynam. 2019, 53, 1567-1580. [CrossRef]

28. Beschel, R.E.; Webb, D. Growth ring studies on arctic willow. In Axel Heiberg Island: Preliminary Report; McGill University: Montreal, QC, Canada, 1962; pp. 189-198.

29. Kuivinen, K.C.; Lawson, M.P. Dendroclimatic Analysis of Birch in South Greenland. Arct. Alp. Res. 1982, 14, $243-250$.

30. Vinther, B.M.; Johnsen, S.J.; Andersen, K.K.; Clausen, H.; Hansen, A.W. NAO signal recorded in the stable isotopes of Greenland ice cores. Geophys. Res. Lett. 2003, 30, 40-41. [CrossRef]

31. Xu, C.; Zheng, H.; Nakatsuka, T.; Sano, M. Oxygen isotope signatures preserved in tree ring cellulose as a proxy for AprilSeptember precipitation in Fujian, the subtropical region of southeast China. J. Geophys. Res. Atmos. 2013, 118, 12805. [CrossRef]

32. Green, J. Wood cellulose. In Method in Carbohydrate Chemistry; Whistler, R.L., Ed.; Academic: San Diego, CA, USA, $1963 ;$ pp. 9-21.

33. Loader, N.; Robertson, I.; Barker, A.; Switsur, V.; Waterhouse, J. An improved technique for the batch processing of small wholewood samples to a-cellulose. Chem. Geol. 1997, 136, 313-317. [CrossRef]

34. Wigley, T.; Briffa, K.; Jones, P. On the average of correlated time series, with applications in dendroclimatology and hydrometeorology. J. Clim. Appl. Meteorol. 1984, 23, 201-213. [CrossRef]

35. Vicente-Serrano, S.M.; Beguería, S.; López-Moreno, J.I.; Angulo, M.; El Kenawy, A. A New Global 0.5 Gridded Dataset (19012006) of a Multiscalar Drought Index: Comparison with Current Drought Index Datasets Based on the Palmer Drought Severity Index. J. Hydrometeorol. 2010, 11, 1033-1043. [CrossRef]

36. Barnston, A.G.; Livezey, R.E. Classification, Seasonality and Persistence of Low-Frequency Atmospheric Circulation Patterns. Mon. Weather. Rev. 1987, 115, 1083-1126. [CrossRef]

37. Leavitt, S. Tree-ring C-H-O isotope variability and sampling. Sci. Total Environ. 2010, 408, 5244-5253. [CrossRef]

38. Naulier, M.; Savard, M.; Bégin, C.; Marion, J.; Arseneault, D.; Bégin, Y. Carbon and oxygen isotopes of lakeshore black spruce trees in northeastern Canada as proxies for climatic reconstruction. Chem. Geol. 2014, 37-43. [CrossRef]

39. Johnsen, S.J.; Dahljensen, D.; Dansgaard, W.; Gundestrup, N. Greenland palaeotemperatures derived from GRIP bore hole temperature and ice core isotope profiles. Tellus B 1995, 47, 624-629. [CrossRef] 
40. Vinther, B.M.; Jones, P.D.; Briffa, K.R.; Clausen, H.; Andersen, K.K.; Dahl-Jensen, D.; Johnsen, S. Climatic signals in multiple highly resolved stable isotope records from Greenland. Quat. Sci. Rev. 2010, 29, 522-538. [CrossRef]

41. West, A.G.; Hultine, K.R.; Burtch, K.G.; Ehleringer, J.R. Seasonal variations in moisture use in a piñon-juniper woodland. Oecologia 2007, 153, 787-798. [CrossRef]

42. Voelker, S.L.; Wang, S.-Y.S.; Dawson, T.E.; Roden, J.S.; Still, C.J.; Longstaffe, F.J.; Ayalon, A. Tree-ring isotopes adjacent to Lake Superior reveal cold winter anomalies for the Great Lakes region of North America. Sci. Rep. 2019, 9, 4412. [CrossRef]

43. Naulier, M.; Savard, M.M.; Bégin, C.; Gennaretti, F.; Arseneault, D.; Marion, J.; Nicault, A.; Bégin, Y. A millennial summer temperature reconstruction for northeastern Canada using oxygen isotopes in subfossil trees. Clim. Past 2015, 11, 1153-1164. [CrossRef]

44. Jouzel, J.; Alley, R.B.; Cuffey, K.M.; Dansgaard, W.; Grootes, P.; Hoffmann, G.; Johnsen, S.J.; Koster, R.D.; Peel, D.; Shuman, C.A.; et al. Validity of the temperature reconstruction from water isotopes in ice cores. J. Geophys. Res. Space Phys. 1997, 102, 26471-26487. [CrossRef]

45. Savard, M.M.; Bégin, C.; Marion, J.; Arseneault, D.; Bégin, Y. Evaluating the integrity of C and O isotopes in sub-fossilwood from boreal lakes. Palaeogeogr. Palaeoecol. 2012, 348-349, 21-31. [CrossRef]

46. Arseneault, D.; Dy, B.; Gennaretti, F.; Autin, J.; Bégin, Y. Developing millennial tree ring chronologies in the fire-prone North American boreal forest. J. Quat. Sci. 2013, 28, 283-292. [CrossRef]

47. Bennike, O.; Björck, S. Lake sediment coring in South Greenland in 1999. Geol. Surv. Den. Greenl. Bull. 2000, 186, 60-64. [CrossRef]

48. Cremer, H.; Bennike, O.; Wagner, B. Lake sediment evidence for the last deglaciation of eastern Greenland. Quat. Sci. Rev. 2008, 27, 312-319. [CrossRef] 